\title{
Kombinasi Suhu Rendah Dan Lama Penyimpanan Terhadap Sifat Fisik Buah Pepaya California (Carica papaya L.)
}

\section{The Combination of Low Temperature and Storage Period for Physical Properties of California Papaya (Carica papaya L.)}

\author{
Muhammad Sudirman Akilie \\ Program Studi Teknologi Hasil Pertanian, Universitas Ichsan Gorontalo \\ Jl. Achmad Nadjamuddin No. 10, Gorontalo \\ Email: msakili85@gmail.com
}

\begin{abstract}
Fruits are one of the perishable horticultural commodities that need a good postharvest handling practice to reduce decay and fruit caused by microbiology and fungus during the storage period. Low temperature has a vital role to affect the physics properties of fruits. The treatment of low temperature could extend the shelflife and quality of fruits. The objective of this research was to know the effect of combination low temperature and storage period on physical properties of California papaya such as total solid content, weight loss, texture, water content, and color. This research used a factorial completely randomized design with two factors. The first factor was temperature and the second factor was the storage period. The results showed that there were interactions between low temperature and storage period of California papaya. The effect of temperature and storage period also significantly impacted for physical properties of California papaya.
\end{abstract}

Keywords: Low temperature, storage, physics properties, California papaya

\begin{abstract}
Abstrak
Buah-buahan merupakan salah satu komoditas hortikultura yang bersifat mudah rusak (perishable) sehingga perlu penanganan pasca panen yang baik untuk mengurangi kerusakan dan pembusukan akibat serangan mikroba dan jamur selama penyimpanan. Peranan suhu rendah (suhu dingin) dapat mempengaruhi sifat fisik komoditi buah-buahan selama penyimpanan. Penyimpanan pada suhu dingin dapat memperpanjang umur simpan dan mempertahankan kualitasnya. Tujuan dari penelitian ini adalah mengetahui kombinasi suhu rendah dan lama penyimpanan terhadap sifat fisik buah pepaya seperti total padatan terlarut (TPT), susut bobot, tekstur, kadar air dan warna. Penelitian ini menggunakan rancangan acak lengkap faktorial. Faktor Suhu yang digunakan adalah suhu rendah $15^{\circ} \mathrm{C}$ dan suhu ruang $30^{\circ} \mathrm{C}$ sebagai kontrol, serta faktor lama penyimpanan buah pepaya selama 0,3,5 dan 7 hari. Hasil analisis sidik ragam menunjukkan bahwa terdapat interaksi antara faktor suhu rendah dan lama penyimpanan terhadap sifat fisik buah pepaya serta faktor suhu rendah dan lama penyimpanan berpengaruh signifikan jika dibandingkan dengan perlakuan penyimpanan suhu $30^{\circ} \mathrm{C}$ sebagai kontrol.
\end{abstract}

Kata kunci: Suhu rendah, lama penyimpanan, sifat fisik, pepaya California

\section{PENDAHULUAN}

Indonesia adalah Negara yang beriklim tropis kaya akan produksi komoditi hortikultura seperti buah-buahan, meskipun masih mengimpor tetapi juga mengekspor buah di
Benua Asia dan Eropa. Salah satu buah ekspor yang diminati oleh masyarakat adalah buah papaya. Pepaya tergolong buah yang populer dan umumnya digemari oleh sebagian besar penduduk dunia hal ini disebabkan karena selain 
memiliki kandungan gizi juga tekstur daging buahnya yang lunak dengan warna merah atau kuning, rasanya manis dan menyegarkan serta banyak mengandung air. Pepaya California merupakan jenis pepaya yang memiliki keunggulan antara lain, buahnya tidak terlalu besar dengan ukuran antara 0,8-2 kg/buah, berkulit tebal, halus dan mengkilat, berbentuk lonjong, buah matangnya berwarna kuning, rasanya manis, dan daging buahnya kenyal, sehingga buah pepaya ini sangat menjanjikan untuk dijadikan buah ekspor Isnawan, (2011). Tingginya kadar air buah pepaya sekitar $80-90 \%$ menjadikan pepaya komoditas hasil panen yang mudah cepat rusak, sehingga diperlukan penanganan pasca panen yang baik untuk mengurangi susut bobot dan kerusakan fisik. Salah satu faktor yang mempengaruhi selera konsumen adalah kualitas buah. Buah pepaya yang berkualitas baik akan berasa manis, tidak lembek, warna daging buah merah segar, dan kulit buah licin atau tidak ada kecatatan fisik seperti layu, terluka, tergores, memar dan terbelah. Selama penyimpanan, buah pepaya direkomendasikan disimpan pada suhu rendah agar dapat mengurangi peningkatan laju respirasi yang mempengaruhi kualitas fisik buah pepaya selama penyimpanan. Penggunaan suhu rendah menjadi solusi yang umum digunakan untuk penyimpanan berbagai jenis buah karena dapat memperlambat laju respirasinya (Pantastico, 1993). Berdasarkan hasil pengukuran laju respirasi yang diperoleh, bahwa puncak klimakterik yaitu yang ditandai dengan lonjakan produksi $\mathrm{CO} 2$ tercepat terjadi pada suhu $10^{\circ} \mathrm{C}$ dan $15^{\circ} \mathrm{C}$ masing-masing adalah $63 \mathrm{ml} / \mathrm{kg} / \mathrm{jam}$ dan $77.7 \mathrm{ml} / \mathrm{kg} / \mathrm{jam}$ setelah pemeraman. Data laju respirasi terlihat bahwa, semakin lama waktu penyimpanan dan semakin rendah suhu penyimpanan buah papaya maka semakin kecil rata-rata nilai laju respirasi yang dihasilkan Silalahi, (2007). Hasil Penelitian Aidio, (2015) menunjukkan bahwa tingkat kematangan buah pepaya indeks 2 pada suhu $10^{\circ} \mathrm{C}$ lebih baik digunakan untuk menyimpan buah pepaya, karena penerapa suhu rendah $10^{\circ} \mathrm{C}$ pada buah pepaya dapat disimpan sampai dengan hari ke-16. Berdasarkan landasan tersebut maka penelitian ini dilakukan dengan mengunakan kombinasi suhu rendah dan lama penyimpanan terhadap sifat fisik buah pepaya California.

\section{Tujuan penelitian}

Mengetahui pengaruh kombinasi suhu rendah dan lama penyimpanan terhadap sifat fisik buah pepaya California.

\section{Manfaat penelitian}

Manfaat penelitian ini adalah mempelajari pengaruh penggunaan suhu rendah sebagai bagian dari penanganan pascapanen yang baik untuk menyimpan buah pepaya California yang memiliki kadar air yang tinggi selama penyimpanan.

\section{METODOLOGI}

\section{Waktu dan tempat}

Penelitian ini dilaksanakan di Laboratorium Pertanian Terpadu Fakultas Pertanian Universitas Ichsan Gorontalo pada bulan Januari sampai Maret 2020.

\section{Bahan dan alat}

Bahan yang digunakan adalah pepaya California yang didapatkan di pedagang buah di Kota Gorontalo dengan tingkat kematangan 6 berdasarkan indeks warna kulit buah menurut Parbawati et al., (2008). Alat yang digunakan adalah timbangan digital LS21, digital thermometer, Minolta reflectance chromameter CR-400, refractometer brix, CT3 texstur analyzer, electric oven dan lemari pendingin Polytron.

\section{Prosedur penelitian}

Pepaya California tingkat kematangan 6 berdasarkan indeks warna kulit buah kuning kemerahan dan memiliki tekstur cukup lunak. Buah pepaya California disortasi kemudian dicuci dengan air disimpan sesuai perlakuan suhu rendah $15^{\circ} \mathrm{C}$ dan suhu ruang $30^{\circ} \mathrm{C}$ selama $0,3,5$ dan 7 hari. Dilakukan pengukuran parameter pengamatan penelitian yang meliputi total padatan terlarut, berat, warna, tekstur, susut bobot dan kadar air.

\section{Rancangan percobaan}

Penelitian ini menggunakan Rancangan Acak Lengkap (RAL) faktorial dengan 2 faktor dengan 3 kali ulangan. Faktor $1: \mathrm{A}=$ Suhu ruang $30^{\circ} \mathrm{C}$, Suhu dingin $15^{\circ} \mathrm{C}$. Faktor $2: \mathrm{B}=$ Lama 
Penyimpanan $0,3,5$ dan 7 hari. Rumus matematika RAL menurut Matjik, (2006) adalah

$$
\begin{aligned}
& \text { Yijk }=\mu+\alpha i+\beta j+(\alpha \beta) i j+\varepsilon i j k \\
& \text { Yijk }=\text { Nilai Pengamatan } \\
& \mu \quad=\text { nilai merata harapan } \\
& \alpha i=\text { pengaruh faktor suhu } \\
& \beta j \quad=\text { pengaruh faktor lama } \\
& \text { penyimpanan } \\
& (\alpha \beta) i j=\text { pengaruh interaksi suhu dan } \\
& \text { lama penyimpanan } \\
& \varepsilon i j k=\text { pengaruh galat }
\end{aligned}
$$

\section{Susut bobot}

Susut bobot dapat dihitung dengan menggunakan rumus sebagai berikut:

Susut bobot $=\frac{(a-b)}{a} \times 100 \%$

a : berat awal sampel $(\mathrm{g})$

$\mathrm{b}$ : berat akhir sampel $(\mathrm{g})$

\section{Warna}

Pengujian warna daging buah pepaya dilakukan dengan menggunakan alat Minolta Reflectance Chormameter. Prosedur penentuan warna daging buah pepaya adalah sebagai mempersiapkan alat Minolta Reflectance Chormameter (CR-400) untuk pengujian warna. Meletakkan daging buah pada wadah yang tersedia, mengatur kalibrasi awal Chromameter dengan standar $\mathrm{Y}=93,9 ; \mathrm{X}=.3134 ; \mathrm{Y}=.3193$, hasilnya berupa nilai $\mathrm{L}$, a dan $\mathrm{b}$.

\section{Pengukuran kadar air Metode Oven vakum (AOAC 1984)}

Kadar air ditentukan dengan cara pengeringan di dalam oven. Bahan ditimbang sebanyak 10-20 g dimasukkan dalam wadah yang telah diketahui beratnya kemudian dimasukkan kedalam oven yang bersuhu $105^{\circ}$ selama 4 jam. Kemudian sampel didinginkan dalam desikator selama 10 menit dan ditimbang. Sampel dipanaskan lagi selama 1 jam, didinginkan dalam desikator dan ditimbang, perlakuan diulangi sampai tercapai berat konstan (selisih penimbangan berturut-turut tidak lebih dari $0,02 \mathrm{~g}$ )

$$
\% \text { Kadar Air }=\frac{(a-b)}{a} x 100
$$

a : berat awal $(\mathrm{g})$

$\mathrm{b}$ : berat akhir $(\mathrm{g})$

\section{Pengukuran total padatan terlarut (AOAC 1990)}

Total padatan terlarut diukur dengan menggunakan refraktometer Atago PR-210 yang telah diatur pada suhu ruang, kemudian cairan dari buah diletakkan pada prisma refraktometer yang telah dibersihkan terlebih dahulu. Setiap sebelum pembacaan prisma tersebut dikalibrasi menggunakan aquades. Selanjutnya nilai total padatan terlarut ditetapkan dalam satuan ${ }^{\circ}$ Brix.

\section{Pengukuran tekstur (Estiningtyas dan Rustanti, 2004)}

Pengukuran tekstur buah pepaya diukur dengan menggunakan Textur Analyzer TATXPlus. Prinsip kerja tekstur analyzer adalah daya tahan produk oleh adanya gaya tekan dari alat atau kemampuan kembalinya bahan pangan yang ditekan ke kondisi awal setelah beban tekanan dihilangkan.

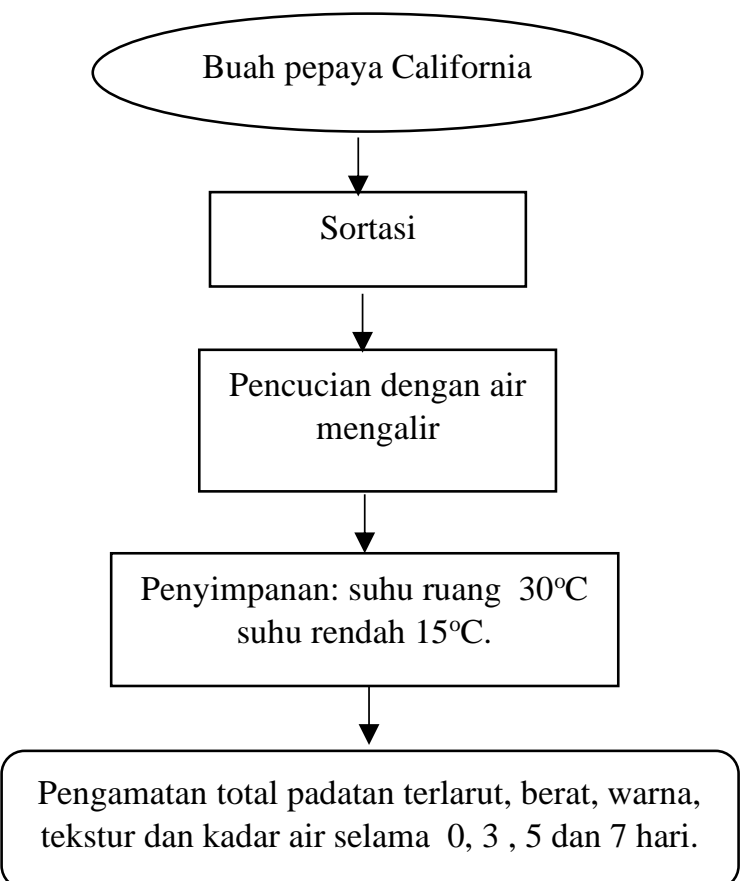

Gambar 1. Bagan alir penelitian

\section{HASIL DAN PEMBAHASAN}


Hasil kombinasi suhu dan lama penyimpanan pada parameter pengamatan sifat fisik buah pepaya California dapat dilihat pada Tabel 1 di bawah ini.

Tabel 1. Kobinasi suhu dan lama penyimpanan terhadap sifat fisik buah pepaya California.

\begin{tabular}{cccccc}
\hline Perlakuan & $\begin{array}{c}\text { TPT } \\
\left({ }^{\circ} \text { brix }\right)\end{array}$ & $\begin{array}{c}\text { Susut Bobot } \\
(\%)\end{array}$ & $\begin{array}{c}\text { Tekstur } \\
(\mathrm{g} / \text { Force })\end{array}$ & $\begin{array}{c}\text { Kadar Air } \\
(\%)\end{array}$ & Warna (L,ab) \\
\hline $30^{\circ} \mathrm{C}$ 0 Hari & $6,93^{\mathrm{c}}$ & $701,60^{\mathrm{a}}$ & $9153,00^{\mathrm{a}}$ & $88,54^{\mathrm{a}}$ & $44,75^{\mathrm{c}}$ \\
$15^{\circ} \mathrm{C}$ 0 Hari & $6,93^{\mathrm{c}}$ & $701,60^{\mathrm{a}}$ & $9153,00^{\mathrm{a}}$ & $88,54^{\mathrm{a}}$ & $44,75^{\mathrm{c}}$ \\
$30^{\circ} \mathrm{C}$ 3 Hari & $8,80^{\mathrm{b}}$ & $675,00^{\mathrm{c}}$ & $7949,00^{\mathrm{ab}}$ & $87,25^{\mathrm{b}}$ & $52,04^{\mathrm{bc}}$ \\
$15^{\circ} \mathrm{C}$ 3 Hari & $7,27^{\mathrm{c}}$ & $691,60^{\mathrm{b}}$ & $8318,00^{\mathrm{ab}}$ & $88,00^{\mathrm{b}}$ & $71,59^{\mathrm{a}}$ \\
$30^{\circ} \mathrm{C}$ 5 Hari & $11,34^{\mathrm{a}}$ & $648,30^{\mathrm{d}}$ & $2184,00^{\mathrm{c}}$ & $86,10^{\mathrm{c}}$ & $55,96^{\mathrm{bc}}$ \\
$15^{\circ} \mathrm{C}$ 5 Hari & $7,47^{\mathrm{c}}$ & $690,00^{\mathrm{ab}}$ & $7990,00^{\mathrm{ab}}$ & $87,76^{\mathrm{b}}$ & $53,83^{\mathrm{bc}}$ \\
$30^{\circ} \mathrm{C}$ 7 Hari & $9,43^{\mathrm{b}}$ & $631,60^{\mathrm{e}}$ & $936,20^{\mathrm{c}}$ & $86,00^{\mathrm{c}}$ & $58,90^{\mathrm{b}}$ \\
$15^{\circ} \mathrm{C}$ 7 Hari & $8,80^{\mathrm{b}}$ & $686,60^{\mathrm{bc}}$ & $7138,00^{\mathrm{b}}$ & $87,26^{\mathrm{b}}$ & $50,22^{\mathrm{bc}}$ \\
\hline
\end{tabular}

Keterangan : Superskrip huruf yang berbeda pada kolom tabel yang sama menunjukkan pengaruh nyata pada uji Duncan 5\%.

\section{Total padatan terlarut}

Total padatan terlarut merupakan suatu cara untuk menguji kadar total padatan terlarut dalam suatu bahan makanan. Gula merupakan komponen utama dalam zat padat terlarut sehingga jauh lebih mudah mengukur total padatan terlarut yakni hanya dengan mengukur kadar gula buah. Hasil analisis sidik ragam menunjukan bahwa suhu dan lama penyimpanan memberikan pengaruh signifikan terhadap total padatan terlarut, serta terdapat interaksi suhu dan lama penyimpanan terhadap total padatan terlarut. Berdasarkan uji lanjut Duncan perlakuan kontrol sama dengan perlakuan hari ke-3, dan hari ke-5 pada suhu $15^{\circ} \mathrm{C}$, namun berbeda dengan perlakuan pada hari ke-3, hari ke-5 dan hari ke-7 pada suhu $30^{\circ} \mathrm{C}$. Nilai total padatan terlarut tertinggi adalah perlakuan dengan suhu $30^{\circ} \mathrm{C}$ dan lama penyimpanan 5 hari. Hal ini diduga karena tingkat kematangan dan umur panen yang tidak seragam pada buah pepaya menyebabakan nilai total padatan terlarut setiap perlakuan berbeda. Hal ini didukung oleh hasil penelitian Taris dkk., 2015 bahwa umur petik mempengaruhi kandungan padatan terlarut total dan kandungan vitamin $\mathrm{C}$ semakin tinggi dengan bertambahnya umur panen buah pepaya Calina. Peningkatan padatan terlarut total ini disebabkan pada tahap awal perkembangan buah, glukosa adalah gula dominan. Perubahan total padatan terlarut disebabkan oleh proses pematangan buah yang diawali dengan pemecahan pati menjadi gula sederhana dan adanya penumpukan gula yang digunakan sebagai substrat selama proses respirasi (Winarno, 2004). Total padatan terlarut mengidentifikasikan tingkat kemanisan pada buah. Semakin tinggi nilai total padatan terlarut maka semakin manis buah tersebut. Hasil penelitian Wills dan Widjanarko, (1995) menunjukkan kandungan padatan terlarut daging buah pepaya Australia meningkat sejalan dengan meningkatnya stadia kematangan buah. Kisaran nilai padatan terlarut pada buah papaya California adalah $6-11^{\circ}$ brix relative sama dengan hasil penelitian Pratiwi, dkk (2013), menunjukkan bahwa kandungan total padatan terlarut buah pepaya Callina yang disimpan dengan $\mathrm{KMnO} 4$ yaitu berkisar antara $8,57-9,91^{\circ}$ brix.

\section{Susut Bobot}

Susut bobot merupakan proses penurunan berat buah akibat proses respirasi, transpirasi dan aktivitas bakteri. Respirasi yang terjadi pada buah merupakan proses biologis dimana oksigen diserap untuk membakar bahan-bahan organik dalam buah untuk menghasilkan energi yang diikuti oleh pengeluaran sisa pembakaran berupa gas karbondioksida dan air (Pantastico, 1993). Air dan gas yang dihasilkan, serta energi berupa panas akan mengalami penguapan sehingga buah tersebut akan menyusut beratnya. Hasil analisis sidik ragam menunjukkan bahwa suhu dan lama penyimpanan memberikan pengaruh signifikan terhadap susut bobot, serta terdapat interaksi suhu dan lama penyimpanan terhadap susut bobot. Berdasarkan uji lanjut Duncan nilai perlakuan kontrol atau penyimpanan suhu ruang sama dengan penyimpanan suhu rendah pada lama 
penyimpanan 5 hari namun berbeda dengan penyimpanan suhu ruang dan suhu dingin pada lama penyimpanan 3 dan 7 hari. Susut bobot papaya California pada suhu ruang dipengaruhi oleh tingginya suhu selama penyimpanan sehingga dapat mempercepat proses respirasi dan transpirasi yang mengubah gula menjadi $\mathrm{CO}_{2}$ dan $\mathrm{O}_{2}$. Hasil penelitian menunjukkan bahwa Semakin lama buah pepaya California disimpan maka buah tersebut akan mengalami penyusutan berat atau bobot. Hal ini juga sesuai dengan pendapat Syarif dan Irawati (1986), bahwa penyusutan berat bahan terus berlangsung selama penyimpanan akibat proses respirasi dan transpirasi. Suhu rendah lebih mampu menekan susut bobot buah selama penyimpanan yaitu dengan memperlambat laju respirasi dan mengurangi laju transpirasi. Menurut Siagian (2009) kehilangan berat buah terjadi karena adanya proses respirasi dan transpirasi pada buah. Meningkatnya respirasi buah menyebabkan perombakan senyawa seperti karbohidrat yang menghasilkan $\mathrm{CO} 2$, energi dan air yang menguap dari permukaan kulit buah.

\section{Tekstur}

Nilai kekerasan merupakan salah satu indikasih kematangan buah. Makin cepat proses pemasakan maka makin cepat pula proses respirasi, dimana ikatan selulosa pada dinding sel makin cepat mengalami kerusakan dan makin cepat pula dinding sel akan mengalami perubahan sehingga buah menjadi cepat lunak. Hasil analisis sidik ragam menunjukan bahwa faktor suhu dan lama penyimpanan memberikan pengaruh signifikan terhadap tekstur, serta terdapat interaksi suhu dan lama penyimpanan terhadap tekstur buah. Berdasarkan uji lanjut Duncan perlakuan kontrol sama dengan perlakuan pada penyimpanan suhu ruang dan rendah pada lama penyimpanan 3 dan 5 hari tetapi berbeda signifikan terhadap lama penyimpanan 5 dan 7 hari pada suhu ruang dan rendah, namun memberikan perbedaan signifikan dengan penyimpanan suhu ruang. Sedangkan nilai tekstur terendah ditunjukkan pada perlakuan suhu ruang dan lama penyimpanan 7 hari sebesar 923.27 g/Force. Nilai tekstur yang rendah menandakan bahwa tekstur buah masih kuat dan keras sementara nilai tekstur tinggi menandakan buah lunak. Menurut Muchtadi (2010), kekerasan buah menurun (lunak) karena hemiselulosa dan protopektin terdegradasi. Protopektin menurun jumlahnya karena berubah menjadi pektin yang bersifat larut. Lunaknya tekstur buah pepaya California juga disebabkan oleh penyimpanan suhu ruang yang dapat mempercepat proses pematangan buah akibat meningkatnya laju respirasi. Semakin lama waktu penyimpanan dan semakin rendah suhu penyimpanan buah papaya maka semakin kecil rata-rata nilai laju respirasi yang dihasilkan Silalahi, (2007).

\section{Kadar Air}

Kadar air merupakan banyaknya air yang terkandung dalam bahan pangan yang dinyatakan dalam persen (Winarno, 2004). Kehilangan air dari hasil holtikultura merupakan penyebab utama dari kerusakan selama penyimpanan, kehilangan air dalam skala yang lebih sedikit masih dapat ditolerir, namun demikian bila kehilangan air lebih besar dapat mengakibatkan bahan menjadi layu atau berkerut. Hasil analisis sidik ragam bahwa faktor suhu dan lama penyimpanan memberi pengaruh signifikan terhadap kadar air, serta terdapat intraksi suhu dan lama penyimpanan terhadap kadar air. Berdasarkan uji lanjut Duncan nilai perlakuan kontrol berbeda dengan perlakuan suhu ruang dan suhu rendah pada lama penyimpanan 3, 5 dan 7 hari. Lama penyimpanan hari ke-7 mengalami penurunan kadar air, dikarenakan buah terus menerus mengalami transpirasi selama penyimpanan baik pada suhu $15^{\circ} \mathrm{C}$ dan $30^{\circ} \mathrm{C}$. Namun terjadi perbedaan yang signifikan antara keduanya dari hari ke-3 hari ke-5 dan hari ke-7. Kisaran kadar air pada buah California pada penelitian ini selama penyimpanan 7 hari yang dikombinasikan pada suhu rendah dan ruang adalah 86-88\%. Penelitian Suyanti (2011) sifat fisik kadar air pada buah papaya madu berkisar 83-89\% dengan lama penyimpanan 2-6 hari.

\section{Warna}

Menurut Winarno, 2004 bahwa warna yang ada pada buah-buahan disebabkan oleh pigmen yang dikandungnya. Pigmen tersebut pada umumnya dibagi menjadi empat kelompok yaitu klorofil, antosianin, flavonoid dan karotenoid. Pada umumnya warna dan penampilan adalah faktor penentu bagi konsumen untuk menyatakan dapat diterima atau ditolaknya buah-buahan dan 
sayuran. Setiap jenis buah, bahkan setiap varietasnya, mempunyai warna kulit yang khas dan merupakan cara terbaik untuk mengukur tingkat kematangan buah. Hasil analisis sidik ragam menunjukan bahawa faktor suhu dan lama penyimpanan memberikan pengaruh signifikan terhadap warna, serta terdapat interaksi suhu dan lama penyimpanan terhadap warna. Berdasarkan uji lanjut Duncan perlakuan kontrol berbeda dan lebih rendah tingkat kecerahan dengan perlakuan pada suhu $15^{\circ} \mathrm{C}$ dan $30^{\circ} \mathrm{C}$. Berdasarkan hasil analisis warna yang dilakukan pada buah pepaya California menunjukan nilai dengan perlakuan suhu $30^{\circ} \mathrm{C}$ dan $15^{\circ} \mathrm{C}$ selama 0 hari sebesar 44,75 , suhu $30^{\circ} \mathrm{C}$ selama 3 hari sebesar 52,04, suhu $15^{\circ} \mathrm{C}$ selama 3 hari sebesar 71,59 , suhu $30^{\circ} \mathrm{C}$ selama 5 hari sebesar 55,96 , suhu $15^{\circ} \mathrm{C}$ selama 5 hari sebesar 53,83 , suhu $30^{\circ} \mathrm{C}$ selama 7 hari 58,90 dan suhu $15^{\circ} \mathrm{C}$ selama 7 hari sebesar 50,22. Hasil penelitian menunjukan bahwa tingkat kecerahan buah cenderung fluktuatif. Nilai tertinggi terdapat pada perlakuan suhu $15^{\circ} \mathrm{C}$ selama 3 hari dengan nilai 71,59 sedangkan tingkat kecerahan terendah terdapat pada perlakuan suhu $30^{\circ} \mathrm{C}$ selama 0 hari dan suhu $15^{\circ} \mathrm{C}$ selama 3 hari A1 B1 dengan nilai 44,75 .

\section{KESIMPULAN}

Kesimpulan pada penelitian ini adalah perlakuan terbaik adalah suhu $15^{\circ} \mathrm{C}$ selama 3 hari. Perlakuan kombinasi uhu $30^{\circ} \mathrm{C}$ dan $15^{\circ} \mathrm{C}$ selama penyimpanan $0,3,5$ dan 7 berpengaruh signifikan terhadap sifat fisik buah pepaya California yang meliputi susut bobot, total padatan terlarut, tekstur, kadar air dan warna. Terdapat interaksi antara kombinasi suhu rendah $15^{\circ} \mathrm{C}$ dan lama penyimpanan 3,5 dan 7 hari pada sifat fisik buah pepaya California.

\section{DAFTAR PUSTAKA}

Aidio, Fitri (2015) Pengaruh Suhu Terhadap Umur Simpan Buah Pepaya (Carica pepaya, L.) Pada Beberapa Tingkat Kematangan. Diploma thesis, Universitas Andalas.

AOAC. 1984. Official Method of Analysis of The Association of Official Analytical chemistry. $14^{\text {th }} \mathrm{Ed}$, Virginia.
AOAC. 1990. Official Methods of Analysis. Washington: Association of Official Analytycal Chemist.

Isnawan Y. 2011. Budidaya Pepaya California. http://epetani.pertanian.go.id/budidaya/ budidayapepayacalifornia-8481 Agustus 2014].

Matjik AA, Sumertajaya, M. 2006. Perancangan Percobaan dengan Aplikasi SAS dan Minitab. Bogor : IPB Press.

Muchtadi TR, Sugiyono, dan Fitriyono A. 2010. Ilmu Pengetahuan Bahan Pangan. Alfabeta. Bandung. Pantastico, E.R.B. 1993. Fisiologi Pasca Panen. Gadja Mada Unversity Press, Yogyakarta.

Prabawati S et al. 2008. Teknologi Pascapanen dan Teknik Pengolahan Buah Pisang. Balai Besar Penelitian dan Pengembangan Pascapanen Pertanian Badan Penelitian dan Pengembangan Pertanian. Bogor.

Pratiwi HE. Suketi K, dan Widodo WD. 2013. Aplikasi Kalium Permanganat sebagai Oksidan Etilen dalam Penyimpanan Buah Pepaya IPB Callina. Seminar Ilmiah Perhorti.

Siagian HF. 2009. Penggunaan Bahan Penjerap Etilen pada Penyimpanan Pisang Barangan dengan Kemasan Atmosfer Termodifikasi Aktif [Skripsi]. Medan: Departemen Teknologi Pertanian, Fakultas Pertanian Universitas, Sumatera Utara.

Silalahi, Elly Nurida 2007. Pengaruh Suhu Dan Lama Penyimpanan Terhadap Mutu Pepaya (Carica papaya L.) IPB 1 Setelah Pemeraman. Skripsi,IPB University.

Suyanti, 2011. Peranan Teknologi Pascapanen Untuk Meningkatkan Mutu Buah Pepaya. Buletin Teknologi Pascapanen Pertanian Volume 7 No 2.

Syarif R dan Anies I. 1986. Pengetahuan Bahan untuk Industri Pertanian. Mediyatama Sarana Pertanian, Jakarta.

Taris, Widodo, dan Suketi. 2015. Kriteria Kemasakan Buah Pepaya (Carica pepaya L.) IPB Callina dari Beberapa Umur Panen. J. Hort. Indonesia 6(3): 172-176. Desember 2015. 
Wills, R.B.H., S.B. Widjanarko. 1995. Changes in physiology, composition and sensory characteristics of Australian pepaya during ripening. Aust. J. Exp. Agric. 35:1173-1176.

Winarno, F.G. 2004. Kimia Pangan dan Gizi. Gramedia Pustaka Utama, Jakarta. 